\title{
Plant polyphenols associated with vitamin E can reduce plasma lipoperoxidation in dairy cows given n-3 polyunsaturated fatty acids
}

\author{
M. Gobert, ${ }^{*}$ B. Martin, ${ }^{*}$ A. Ferlay, ${ }^{*}$ Y. Chilliard, ${ }^{*}$ B. Graulet, ${ }^{*}$ P. Pradel, $†$ D. Bauchart, ${ }^{*}$ and D. Durand ${ }^{* 1}$ \\ *INRA, UR1213 Herbivores, Centre de Clermont-Ferrand/Theix, F-63122 St-Genès-Champanelle, France \\ †INRA, UE1296 des Monts d'Auvergne, F-63210 Orcival, France
}

\begin{abstract}
Diets rich in n-3 polyunsaturated fatty acids (PUFA) improve the nutritional value of ruminant products but also increase the risk of lipoperoxidation in plasma and tissues. The relative effectiveness of dietary antioxidants such as vitamin $\mathrm{E}$ (vit E) given alone or with plant extracts rich in polyphenols (PERP) containing rosemary, grape, citrus, and marigold was investigated in the plasma of mid-lactation dairy cows given diets enriched in 18:3 n-3. For a 30-d period, the animals were given a maize silage-based diet (control group $\mathrm{C}, \mathrm{n}=$ 6 ) or the same basal diet supplemented with extruded linseed rich in 18:3 n-3 [50 g of oil/ $\mathrm{kg}$ of diet dry matter $(\mathrm{DM})$; group $\mathrm{L}, \mathrm{n}=6]$, extruded linseed + vit $\mathrm{E}(375$ international units $/ \mathrm{kg}$ of diet $\mathrm{DM} ; 7,500 \mathrm{IU} /$ cow per day; group LE, $\mathrm{n}=6$ ), or extruded linseed + vit $\mathrm{E}+$ PERP $(10 \mathrm{~g} / \mathrm{kg}$ of diet DM; group LEP, $\mathrm{n}=5)$. Plasma susceptibility to lipoperoxidation was evaluated using in vitro parameters of conjugated diene formation (lag phase and maximum oxidation rate). Plasma indicators of lipoperoxidation and antioxidant status were analyzed in the 4 experimental groups as well as the fatty acid (FA) composition of total plasma lipids. At d 30, group L significantly increased plasma cholesterol esters $(+57 \%)$ and phospholipids $(+35 \%)$ compared with group C. It also increased plasma n-3 PUFA (4.7-fold increase) to the detriment of n-6 PUFA $(-30 \%)$, leading to a higher peroxidizability index $(+20 \%)$. Plasma in vitro lipoperoxidation was higher in group L, rich in 18:3 n-3, than in group C. Vitamin $\mathrm{E}$ alone had no effect on lipoperoxidation, whereas vit $\mathrm{E}$ in association with PERP lowered lipoperoxidation by increasing the resistance time against peroxidation $(+47 \%)$ and by decreasing the oxidation rate $(-48 \%)$ compared with group L at d 30. Surprisingly, in vivo plasma lipoperoxidation estimated by the plasma level of the major lipoperoxidation product (malondialdehyde) was not significantly increased in group L. This study shows, for
\end{abstract}

Received January 29, 2009

Accepted August 10, 2009.

${ }^{1}$ Corresponding author: durand@clermont.inra.fr the first time, that PERP supplied in association with vit $\mathrm{E}$ were able to reduce lipoperoxidation in lactating cows given a diet rich in 18:3 n-3, thereby helping to protect cows against the deleterious consequences of lipoperoxidation and potentially ensuring antioxidant potential for 18:3 n-3-enriched dairy products.

Key words: 18:3 n-3, lipoperoxidation, antioxidant, plasma

\section{INTRODUCTION}

To improve the nutritional quality of dairy products for consumers, lipid supplementation of ruminant diets with n-3 polyunsaturated fatty acids (PUFA)-rich oilseeds is a rapid and effective feed strategy (Chilliard et al., 2007). However, this strategy could increase the risk of plasma lipoperoxidation, as reported in steers (Scislowski et al., 2005a), rats (Gladine et al., 2007) and sheep [C. Gladine, E. Rock, C. Morand (all of INRA, UMR1019, St-Genès-Champanelle, France), D. Bauchart, D. Durand (both of INRA, UR1213, StGenès-Champanelle, France); unpublished data]. This could not only be detrimental to animal health (Miller et al., 1993) but also decrease the nutritional value of their products, thus prompting recommendations to add antioxidants to lipid-enriched diets. Vitamin E (vit E) is commonly added to animal and human diets because of its ability to inhibit lipoperoxidation (Cuvelier et al., 2003). This lipophilic antioxidant inactivates the lipid peroxyl radicals and thus acts as a chain-breaking antioxidant limiting the propagation of the oxidation reaction by capturing radical electrons (Brigelius-Flohe and Traber, 1999; Goupy et al., 2007). However, in rats and sheep given 18:3 n-3-enriched diets, vit E supplementation (200 IU/kg of diet DM; $300 \mathrm{IU} /$ sheep per day) did not effectively prevent lipoperoxidation chain reactions [Gladine et al., 2007; C. Gladine, E. Rock, C. Morand (all of INRA, UMR1019, St-Genès-Champanelle, France), D. Bauchart, D. Durand (both of INRA, UR1213, St-Genès-Champanelle, France); unpublished data]. One option for improving vit E's protective effect against lipoperoxidation could be to increase the dietary vit $\mathrm{E}$ level, but high dietary concentrations of 
vit $\mathrm{E}$ would not be efficient because the excess vit $\mathrm{E}$ would be catabolized or excreted (Aurousseau, 2002). A study on rats and guinea pigs showed that tocopherol excretion in the feces increased significantly according to vitamin $\mathrm{E}$ intake (0.03 to $10 \mathrm{~g} / \mathrm{kg}$ of diet), and tocopherol absorption rate was inversely proportional to level of supply (Elmadfa and Walter, 1981). Moreover, high-dosage vit E supplements may be deleterious to animals: a meta-analysis on humans had shown that high-dosage vit $\mathrm{E}$ supplements $(\geq 400 \mathrm{IU} / \mathrm{d})$ increased all-cause mortality and should be avoided (Miller et al., 2005). In this context, new dietary antioxidant molecules given in combination with vitamin $\mathrm{E}$ could be more effective for preventing plasma lipoperoxidation. Plant polyphenols are known to play an important protective role in the lipoperoxidation process. Human studies have demonstrated better protection against oxidative damage and related diseases when a variety of fruit and vegetable-based antioxidants are consumed (Jacob and Burri, 1996) and have shown inhibition of carcinogenesis by dietary polyphenolic compounds (Yang et al., 2001). In a ruminant husbandry context, polyphenolic compounds abundant in fresh grass were partially recovered as active molecules in the ruminant milk (King et al., 1998). Recent studies in rats (Gladine et al., 2007) and sheep [C. Gladine, E. Rock, C. Morand (all of INRA, UMR1019, St-Genès-Champanelle, France), D. Bauchart, D. Durand (both of INRA, UR1213, StGenès-Champanelle, France); unpublished data] given 18:3 n-3-supplemented diets proved the effectiveness and complementary effect of a mixture of plant extracts rich in polyphenol (PERP) and vit E against plasma and tissue lipoperoxidation. This effect was probably because of the hydrophilic properties of PERP exhibiting affinity for different parts of cells complementary to the lipophilic vit E (Yeum et al., 2004). The present study aimed to analyze 1) the putative stimulatory effect of 18:3 n-3 from linseed (50 g of oil $/ \mathrm{kg}$ of diet DM) on plasma lipoperoxidation in mid-lactation dairy cows and 2) the effectiveness of dietary vit $\mathrm{E}(375 \mathrm{IU} / \mathrm{kg}$ of diet DM per day) provided alone or with PERP (10 g/ $\mathrm{kg}$ of diet DM per day) to optimize protection against plasma lipoperoxidation (Miller et al., 1993).

\section{MATERIALS AND METHODS}

\section{Animals and Treatments}

The experiment was performed with 24 cows (12 Holstein, 12 Montbéliarde) calving between November 2006 and January 2007, and selected on similar weight, lactation stage, milk production, and milk chemical composition, in the INRA experimental herd of Marcenat (France). During a 3-wk preexperimental period, animals were given a daily diet based on hay and maize silage ad libitum with a cereal mixture $(70 \%$ barley and 30\% maize) and soybean meal individually adapted according to the daily milk yield (DMY). At the end of the preexperimental period (d 0), mean BW was $647 \pm 47 \mathrm{~kg}$, lactation stage was $67 \pm 16 \mathrm{~d}$, DMY was $31.7 \pm 5.7 \mathrm{~kg}$, and milk fat and protein contents were $39.2 \pm 3.3$ and $31.6 \pm 1.7 \mathrm{~g} / \mathrm{kg}$, respectively. The animals were assigned at random to 4 rations for $30 \mathrm{~d}$ (3 Holstein and 3 Montbéliarde cows per group) after a 3 -d transition period. Chemical composition of the experimental diets, as detailed by Ferlay et al. (2009), are summarized in Table 1. Animals of the control group (C) were given maize silage ad libitum at $0930 \mathrm{~h}$ and grassland hay (7.9\% of DMI) at $1500 \mathrm{~h}$ supplemented with cereal mixture (70\% barley and $30 \%$ maize; $14.2 \%$ of DMI) and $12.7 \%$ of DMI of soybean meal. A second group was given the same basal diet supplemented with $10.1 \%$ of DMI of soybean meal and $17.9 \%$ of DMI of extruded linseed providing $50 \mathrm{~g}$ of oil $/ \mathrm{kg}$ of DM (group L). A third group was given diet L supplemented with DL- $\alpha$-tocopherol acetate (375 IU/ $\mathrm{kg}$ of diet DM; 7,500 IU/cow per day; group LE). Animals in the final group were given diet LE supplemented with a mixture of 4 PERP (10 g/ $\mathrm{kg}$ of diet DM; group LEP). The PERP were prepared from rosemary (Rosemarinus officinalis), grape (Vinis vitifera), citrus (Citrus paradisi), and marigold (Calendula officinalis) by Phytosynthèse (Riom, France); this mixture was patented (patent \#P170-B-23.495 FR) by INRA on September 19, 2006. In the 4 experimental groups, rations were adjusted to individual animal requirements to cover energy and protein needs (INRA, 1988). The linseed, vitamin E, and PERP were mixed with maize silage and offered in the morning meal. The cows were housed in a tie-stall barn and milked at 0600 and $1600 \mathrm{~h}$.

\section{Blood Samples}

Blood samples $(60 \mathrm{~mL})$ were collected just before the morning meal on d 0 and d 30 of the experimental period. Samples were taken from the jugular vein into tubes containing various anticoagulants: $\mathrm{K}_{3}$-EDTA $(0.47 \mathrm{~mol} / \mathrm{L})$ tubes were used to determine plasma lipids (only at d 30), fatty acid (FA) composition, $\alpha$-tocopherol, and malondialdehyde (MDA); lithium heparin $(5 \mathrm{IU} / \mathrm{mL}$ ) tubes were used to determine plasma total antioxidant status (TAS; expressed as Trolox-equivalent antioxidant capacity, TEAC) and liver enzyme activities; and sodium citrate $(18 \mathrm{mM})$ tubes were used to determine the kinetics of in vitro conjugated diene (CD) production. All plasma samples were isolated from blood by centrifugation at 1,600 $\times$ $g$ for 10 min at $4^{\circ} \mathrm{C}$ and stored at $-80^{\circ} \mathrm{C}$ until vit $\mathrm{E}$, 
Table 1. Experimental diet compositions

\begin{tabular}{lcccc}
\hline & \multicolumn{4}{c}{ Experimental diet $^{1}$} \\
\cline { 2 - 5 } Item & $\mathrm{C}$ & $\mathrm{L}$ & $\mathrm{LE}$ & LEP \\
\hline Total DMI (kg/d) & 21.4 & 19.3 & 19.1 & 20.3 \\
Main ingredients (\% of DMI) & & & & \\
Total forage (maize silage + hay) & 12.2 & 71.3 & 68.2 & 69.8 \\
Barley + maize & 12.7 & 10.0 & 1.6 & 0.3 \\
Soybean meal & 0.0 & 17.6 & 17.6 & 10.7 \\
Extruded linseed & 0.94 & 1.04 & 1.05 & 0.99 \\
Mineral and vitamin mix ${ }^{2}$ & 0.0 & 0.0 & 0.078 & 0.074 \\
Vitamin E & 0.0 & 0.0 & 0.0 & 0.99 \\
Plant extracts rich in polyphenols &
\end{tabular}

${ }^{1}$ Cows were given a maize-silage-based diet (control, $\mathrm{C}, \mathrm{n}=6$ ) or the same diet enriched with 18:3 n-3 from extruded linseed $(50 \mathrm{~g}$ of oil $/ \mathrm{kg}$ of diet $\mathrm{DM})$ provided alone $(\mathrm{L}, \mathrm{n}=6)$ or with vitamin $\mathrm{E}(375 \mathrm{IU} / \mathrm{kg}$ of diet DM; $\mathrm{LE}, \mathrm{n}=6)$, or with vitamin E plus plant extracts rich in polyphenols $(10 \mathrm{~g} / \mathrm{kg}$ of diet DM; LEP, $\mathrm{n}=5)$.

${ }^{2}$ Mineral and vitamin mix contained per kilogram: $5 \mathrm{~g}$ of P, $20 \mathrm{~g}$ of Ca, $4.5 \mathrm{~g}$ of $\mathrm{Mg}, 2 \mathrm{~g}$ of Na, $1 \mathrm{~g}$ of S, 1,400 $\mathrm{mg}$ of $\mathrm{Cu}, 5,000 \mathrm{mg}$ of $\mathrm{Zn}, 4,000 \mathrm{mg}$ of $\mathrm{Mn}, 80 \mathrm{mg}$ of I, $32 \mathrm{mg}$ of Co, and $22 \mathrm{mg}$ of Se, 600,000 IU of vitamin A, $120,000 \mathrm{IU}$ of vitamin $\mathrm{D}_{3}, 1,500 \mathrm{IU}$ of vitamin $\mathrm{E}$, and $400 \mathrm{mg}$ of vitamin $\mathrm{B}_{1}$.

TAS, CD, and MDA analysis or at $-20^{\circ} \mathrm{C}$ for plasma lipid and liver enzyme determination.

\section{Plasma Analysis}

Lipid Classes. Plasma phospholipids (PL), cholesteryl esters (CE), triacylglycerols (TG), free cholesterol (FC), and NEFA were determined enzymatically as described by Scislowski et al. (2005a). Plasma PL were determined by Trinder's enzymatic method using a Sobioda kit (ref. 1306170, Sobioda, Montbonnot Saint-Martin, France). Analyses of CE and FC were performed with the Cholesterol PAP reagent kit (ref. 1306164), and TG was determined with the Triglycerides LD B reagent kit (ref. 1306148), both supplied by Sobioda. Plasma NEFA was determined using the NEFA C Wako kit (ref. 46551, Unipath SA, Dardilly, France).

FA Analysis and Peroxidizability Index. Plasma lipids were extracted from plasma samples as described by Folch et al. (1957) and their FA were selectively extracted and converted into methyl esters as described previously (Bauchart and Aurousseau, 1981). Quantitative and qualitative FA analyses were performed by GLC using a Peri 2100 chromatograph (Perichrom, Saulx-les-Chartreux, France) equipped with a CP SIL 88 glass capillary column (100 m length, 0.25 i.d). Conditions for GLC analysis were as follows: injector and detector temperatures were 235 and $250^{\circ} \mathrm{C}$, respectively; oven temperature was programmed at $70^{\circ} \mathrm{C}$ for $30 \mathrm{~s}$, then increased from 70 to $175^{\circ} \mathrm{C}$ at $20^{\circ} \mathrm{C} / \mathrm{min}$, held at $175^{\circ} \mathrm{C}$ for $25 \mathrm{~min}$, increased from 175 to $215^{\circ} \mathrm{C}$ at $10^{\circ} \mathrm{C} / \mathrm{min}$, and held at $215^{\circ} \mathrm{C}$ for $41 \mathrm{~min}$; carrier gas was hydrogen $\left(\mathrm{H}_{2}\right.$ flow: $\left.1.1 \mathrm{~mL} / \mathrm{min}\right)$ in split injection conditions $(1 / 50)$. Fatty acids were quantified using
C19:0 as internal standard (Supelco, Bellefonte, PA) and identified by comparing the retention times against FA standards (Supelco). The peroxidizability index (PI) was calculated from the total lipid FA composition according to the equation reported by Scislowski et al. $(2005 \mathrm{~b})$ as follows: PI $=(\%$ dienoic $\mathrm{FA} \times 1)+$ $(\%$ trienoic $\mathrm{FA} \times 2)+(\%$ tetraenoic $\mathrm{FA} \times 3)+(\%$ pentaenoic FA $\times 4)+(\%$ hexaenoic FA $\times 5)$. This PI estimates the concentration of bis-allylic hydrogen atoms present in the PUFA and therefore their susceptibility to peroxidation.

Vit $\boldsymbol{E}$. Plasma vit $\mathrm{E}$ (as the $\alpha$-tocopherol form) was measured by HPLC-UV spectrophotometry adapted to bovine plasma (Scislowski et al., 2005a). $\alpha$-Tocopherol was extracted from $1 \mathrm{~mL}$ of plasma with $850 \mu \mathrm{L}$ of ethanol and $1 \mathrm{~mL}$ of hexane. Extraction yield was determined by using tocopherol acetate added to the plasma sample as internal standard. The hexane phase (containing both $\alpha$-tocopherol and tocopherol acetate) was recovered by centrifugation at $1,200 \times g$ for 10 min at room temperature. The second extraction was performed with $1 \mathrm{~mL}$ of hexane. The hexane phases were pooled and evaporated under an $\mathrm{N}_{2}$ stream, and $\alpha$-tocopherol and tocopherol acetate were solubilized by $150 \mu \mathrm{L}$ of methanol/dichloromethane (65:35; vol/ vol). The HPLC system (Kontron Instruments, Zurich, Switzerland) was equipped with a nucleosil $5-\mu \mathrm{m}$ C18 column $(250 \times 4.6 \mathrm{~mm}$; Interchim, Montluçon, France), and methanol was used as mobile phase (flow rate $1.5 \mathrm{~mL} / \mathrm{min}$ ). Ultraviolet signals (at $292 \mathrm{~nm}$ ) were quantified by using the Kontron "Kroma System 2000" software.

$\boldsymbol{T A} \boldsymbol{S}$. Total antioxidant status was measured by a method based on the absorbance of the $\mathrm{ABTS}^{\circ+}$ cation [2,2'-azinobis-(3-ethylbenzothiazoline-6-sulfonic acid)] 
adapted to bovine plasma, as described by Scislowski et al. (2005a). Briefly, ABTS $^{\circ+}$ production was initiated by adding $450 \mu M$ hydrogen peroxide to a $1-\mathrm{mL}$ quartz cuvette containing $12 \mu \mathrm{L}$ of plasma, $500 \mu \mathrm{M}$ ABTS, and $48.8 \mu M$ metmyoglobin diluted in PBS (5 $\mathrm{m} M$, pH 7.4). Absorbance at $732 \mathrm{~nm}$ was measured immediately $\left(\mathrm{At}_{0}\right)$ and at $3 \mathrm{~min}\left(\mathrm{At}_{3}\right)$ after the addition of hydrogen peroxide at $37^{\circ} \mathrm{C}$ using a Uvikon 923 doublebeam spectrophotometer (Kontron Analysis Division). Absorbance of the blank (i.e., containing PBS instead of plasma) was also determined to calculate the inhibition percentage of the reaction, as follows:

$\%$ inhibition $=\frac{\left(\mathrm{A}_{\mathrm{t} 0}-\mathrm{A}_{\mathrm{t} 3}\right)_{\text {blank }}-\left(\mathrm{A}_{\mathrm{t} 0}-\mathrm{A}_{\mathrm{t} 3}\right)_{\text {plasma }}}{\left(\mathrm{A}_{\mathrm{t} 0}-\mathrm{A}_{\mathrm{t} 3}\right)_{\text {blank }}} \times 100$.

Inhibition percentages were converted into TEAC and expressed as millimole equivalents of Trolox per liter, using a standard curve ranging from 0 to $2.5 \mathrm{mM}$ Trolox, to represent the capacity of plasma to resist oxidation reactions.

Kinetics of CD Generation. Susceptibility of plasma lipids to lipoperoxidation was evaluated by measuring the in vitro kinetics of CD generation induced by the addition of copper ions. Copper chloride $(10 \mathrm{mM})$ was added to each plasma sample and CD absorbance was continuously monitored at $234 \mathrm{~nm}$ for $140 \mathrm{~min}$ at $37^{\circ} \mathrm{C}$ using a Uvikon 923 double-beam spectrophotometer (Kontron Analysis Division). The kinetics of CD generation showed 3 successive phases from which different parameters were calculated as described previously by Esterbauer et al. (1989). This reaction enabled us to evaluate 1) the time of resistance to the initiation of lipoperoxidation by measuring the lag phase (min), 2) lipid susceptibility to peroxidation, by measuring the maximum amount of CD produced (CD max), and 3) the speed of the propagation reaction, estimated by the maximum rate of peroxidation $\left(\mathrm{A}_{234} / \mathrm{min}\right)$ corresponding to the slope of the curve.

$\boldsymbol{M D A}$. Plasma MDA was determined by HPLCfluorescence as described earlier (Agarwal and Chase, 2002). Briefly, $400 \mu \mathrm{L}$ of phosphoric acid $(0.44 M$ in $\mathrm{H}_{2} \mathrm{O}$ ) and $100 \mu \mathrm{L}$ of $0.8 \%$ thiobarbituric acid in $\mathrm{H}_{2} \mathrm{O}$ were added to $50 \mu \mathrm{L}$ of a solution of butyl hydroxytoluene in ethanol $(0.05 \%)$ and $50 \mu \mathrm{L}$ of plasma, and incubated at $100^{\circ} \mathrm{C}$ for $1 \mathrm{~h}$. After cooling in an ice bath and adding $500 \mu \mathrm{L}$ of of $n$-butanol, the mixture was centrifuged at $25,700 \times g$ for $3 \mathrm{~min}$ at room temperature to recover the complex MDA-TBA 2 present in the upper phase. An aliquot $(180 \mu \mathrm{L})$ of this solution was injected into the HPLC System (Perkin Elmer Instruments, Shelton, CT) equipped with an RP C18 column (ODB $5 \mu \mathrm{m}, 4.6$ $\times 250 \mathrm{~mm}$; Interchim). The mobile phase (flow rate: 0.6
$\mathrm{mL} / \mathrm{min})$ consisted of potassium phosphate $(0.05 \mathrm{M}$, $\mathrm{pH}$ 6.8) in methanol. Malondialdehyde was detected by fluorescence (excitation at $515 \mathrm{~nm}$ and emission at 553 $\mathrm{nm}$ ), and its plasma concentration was determined by using a 1,1,3,3-tetraethoxypropane calibration curve.

Liver Enzymes. Plasma concentrations of the liver enzymes alanine aminotransferase (ALAT), aspartate aminotransferase (ASAT), and gamma-glutamyl transpeptidase (GGT) were determined enzymatically. Plasma ALAT was determined by UV detection (340 $\mathrm{nm}$ ) using kinetic tests (RC1160-04) provided by Sobioda. Plasma GGT was measured by using a Biodirect kit (RC1124-03) supplied by Biodirect (Lavilleneuve, France) with colorimetric detection $(405 \mathrm{~nm})$. Plasma ASAT was determined by UV detection $(340 \mathrm{~nm})$ using a Biodirect TGO kinetic test (RC1157-02).

\section{Statistical Analysis}

Data were analyzed using the GLM procedure in SAS (SAS Institute, Cary, NC). Data obtained at d 0 were used as the covariate term. The effect of treatment at $d$ 30 was tested as a fixed effect and declared significant at $P<0.05$ and as trend at $0.05<P<0.1$. Treatment comparisons were run using the PDIFF option of least squares means (LSMeans procedure; SAS Institute).

\section{RESULTS}

\section{Plasma Lipids and FA Composition}

Main plasma lipids (PL, CE, TG, FC, and NEFA) determined on $\mathrm{d} 30$ of the experimental period are given in Table 2. Plasma PL and CE were higher $(+35 \%$ and $+57 \%$, respectively; $P<0.05)$ in animals given the $18: 3$ n-3-rich diet (group L) than in animals in group C. Inversely, plasma FC concentrations decreased $(-44 \% ; P$ $<0.05)$ with group L compared with group C. Plasma TG and NEFA concentrations were not significantly modified by dietary 18:3 n-3 supplementation. Moreover, addition of vit $\mathrm{E}$ alone or vit $\mathrm{E}+\mathrm{PERP}$ did not modify lipid class concentrations in the 18:3 n-3-rich diet group at d 30. Plasma FA composition was analyzed in animals of all 4 groups (Table 3). Addition of extruded linseed rich in 18:3 $\mathrm{n}-3$ in the diet (group L) decreased saturated fatty acids $(-24 \% ; P<0.05)$ to the benefit of monounsaturated fatty acids $(+17 \% ; P$ $<0.05)$ and n-3 PUFA (4.7-fold increase; $P<0.05$ ) compared with that in group $C$. The increase of n-3 PUFA was to the detriment of n-6 PUFA, lowering the $\mathrm{n}-6 / \mathrm{n}-3$ ratio $(1.5$ vs. $8.9, P<0.05)$ in group $\mathrm{L}$ versus group C. Such modification of plasma FA profile in group L increased the PI value (94 vs. $78 \% ; P<0.05$; Table 3). Addition of vit $\mathrm{E}$ or vit $\mathrm{E}+\mathrm{PERP}$ in the 
Table 2. Least squares means (time 0 data used as a covariate) of plasma concentrations (mg/dL) of major lipid classes at d 30 of the experimental period

\begin{tabular}{|c|c|c|c|c|c|c|}
\hline Lipid class $(\mathrm{mg} / \mathrm{dL})$ & \multicolumn{4}{|c|}{ Experimental $\operatorname{diet}^{1}$} & SEM & $\begin{array}{c}P \text {-value } \\
\text { (treatment) }\end{array}$ \\
\hline Phospholipids & $146.0^{\mathrm{a}}$ & $196.8^{\mathrm{b}}$ & $191.3^{\mathrm{b}}$ & $174.7^{\mathrm{ab}}$ & 12.55 & 0.05 \\
\hline Triglycerides & 27.4 & 37.5 & 32.7 & 28.4 & 6.76 & NS \\
\hline Free cholesterol & $9.3^{\mathrm{a}}$ & $5.2^{\mathrm{b}}$ & $4.3^{\mathrm{b}}$ & $4.7^{\mathrm{b}}$ & 1.34 & 0.03 \\
\hline NEFA & 0.16 & 0.33 & 0.21 & 0.18 & 0.07 & NS \\
\hline
\end{tabular}

${ }^{\mathrm{a}, \mathrm{b}}$ Least squares means in the same row with different superscript letters are significantly different, $P<0.05 ;$ NS: $P>0.1$.

${ }^{1}$ Cows were given a maize-silage-based diet (control, $\mathrm{C}, \mathrm{n}=6$ ) or the same diet enriched with 18:3 n-3 from extruded linseed (50 g of oil/kg of diet $\mathrm{DM})$ provided alone $(\mathrm{L}, \mathrm{n}=6)$ or with vitamin $\mathrm{E}(375 \mathrm{IU} / \mathrm{kg}$ of diet $\mathrm{DM} ; \mathrm{LE}, \mathrm{n}=6)$ or with vitamin $\mathrm{E}$ plus plant extracts rich in polyphenols $(10 \mathrm{~g} / \mathrm{kg}$ of diet DM; LEP, $\mathrm{n}=5)$.

18:3 n-3-rich diets did not significantly modify plasma FA composition, and thus had no effect on the PI value compared with the $\mathrm{L}$ diet.

\section{Markers of Liver Function}

Plasma activities of markers of liver function (ALAT, GGT) did not vary significantly with diets (Table 4). However, ASAT activity was $33 \%(P<0.05)$ higher in 18:3 n-3-rich diet groups supplemented or not with antioxidants compared with control group.

\section{Susceptibility of Plasma to Lipoperoxidation}

The susceptibility of plasma lipids to lipoperoxidation was determined by monitoring the in vitro kinetics of CD generation induced by copper salts (Table
5). In plasma, maximum $\mathrm{CD}$ production by radical attacks tended to be $27 \%(P=0.1)$ higher in plasma of cows fed the 18:3 n-3-rich diets (with or without antioxidant supplements) than in the control group. Lag phase duration tended to decrease in plasma of cows given the L diet ( $-13 \%$, not significant) compared with that in the control group. In cows given 18:3 n-3-rich diets, association of vit $\mathrm{E}$ and PERP significantly increased the lag phase value compared with cows in the L and LE groups $(+43 \%$ and $+27 \%$, respectively; $P<0.05$ ). Moreover, speed of $\mathrm{CD}$ production (CD peroxidation rate) was higher in the $\mathrm{L}$ $\operatorname{diet}(+24 \%, P<0.05)$ than in the $\mathrm{C}$ diet. Compared with group $\mathrm{L}$, addition of vit $\mathrm{E}$ in the $\mathrm{LE}$ diet decreased plasma oxidation rate $(-35 \% ; P<0.05)$, but the effect was more marked with vit $\mathrm{E}$ associated with PERP $(-48 \% ; P<0.05)$.

Table 3. Mean fatty acid (FA) composition of total plasma lipids in cows at d 30 of the experimental period

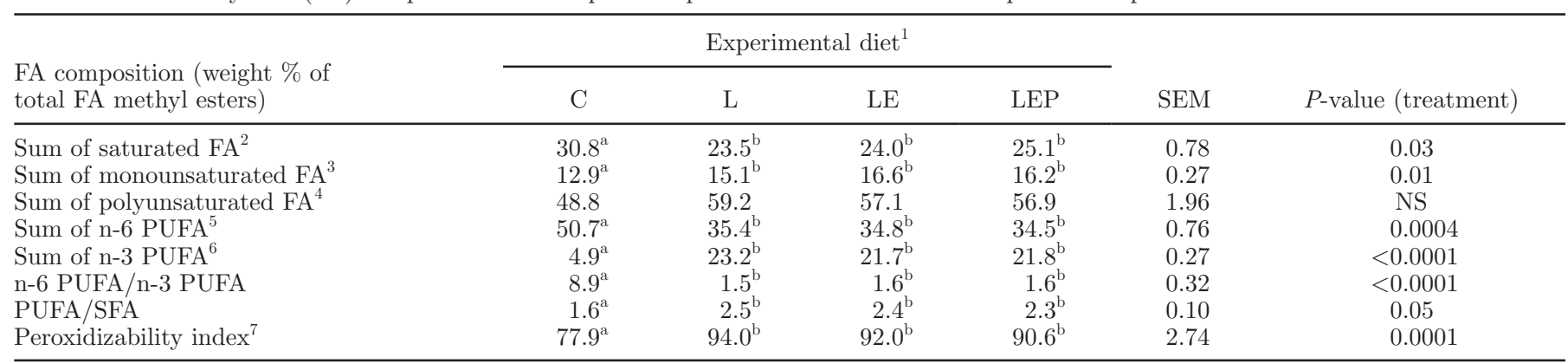

${ }^{\mathrm{a}, \mathrm{b}}$ Means in the same row with different superscript letters are significantly different, $P<0.05$. NS: $P>0.1$.

${ }^{1}$ Cows were given a maize-silage-based diet (control, $\mathrm{C}, \mathrm{n}=6$ ) or the same diet enriched with 18:3 $\mathrm{n}-3$ from extruded linseed (50 g of oil $/ \mathrm{kg}$ of diet $\mathrm{DM})$ provided alone $(\mathrm{L}, \mathrm{n}=6)$ or with vitamin $\mathrm{E}(375 \mathrm{IU} / \mathrm{kg}$ of diet $\mathrm{DM} ; \mathrm{LE}, \mathrm{n}=6)$ or with vitamin E plus plant extracts rich in polyphenols $(10 \mathrm{~g} / \mathrm{kg}$ of diet DM; LEP, $\mathrm{n}=5)$.

${ }^{2} \mathrm{Sum}$ of saturated FA $=\mathrm{C} 12: 0+\mathrm{C} 13: 0+\mathrm{C} 14: 0+\mathrm{C} 15: 0+\mathrm{C} 16: 0+\mathrm{C} 17: 0+\mathrm{C} 18: 0+\mathrm{C} 20: 0+\mathrm{C} 22: 0+\mathrm{C} 24: 0$.

${ }^{3}$ Sum of monounsaturated FA $=\mathrm{C} 14: 1 \mathrm{n}-5+\mathrm{C} 15: 1 \mathrm{n}-6+\mathrm{C} 16: 1 \mathrm{n}-9+\mathrm{C} 16: 1 \mathrm{n}-7+\mathrm{C} 17: 1 \mathrm{n}-8+\mathrm{C} 18: 1 \Delta 9$ cis $+\mathrm{C} 18: 1 \Delta 11$ cis $+\mathrm{C} 18: 1 \Delta 12$ cis +

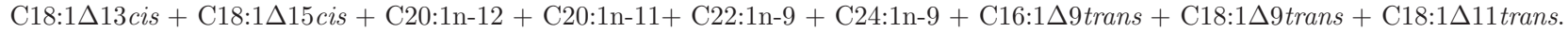

${ }^{4}$ Sum of polyunsaturated FA (PUFA) $=$ sum of n-6 PUFA + sum of n-3 PUFA.

${ }^{5}$ Sum of n- 6 PUFA $=$ C18:2n-6 trans trans $+\mathrm{C} 18: 2 \mathrm{n}-6$ trans cis $+\mathrm{C} 18: 2 \mathrm{n}-6$ cis trans $+\mathrm{C} 18: 2 \mathrm{n}-6$ cis cis $+\mathrm{C} 18: 3 \mathrm{n}-6+\mathrm{C} 20: 2 \mathrm{n}-6+\mathrm{C} 20: 3 \mathrm{n}-6+$ C20:4n-6 + C20:5n-6 + C22:2n-6.

${ }^{6}$ Sum of n-3 PUFA $=$ C18:3n-3 + C20:3n- $3+$ C20:4n-3 + C20:5n-3 + C22:3n-3 + C22:4n-3 + C22:5n-3 + C22:6n-3.

${ }^{7}$ Peroxidizability index $=(\%$ dienoic FA $\times 1)+(\%$ trienoic FA $\times 2)+(\%$ tetraenoic FA $\times 3)+(\%$ pentaenoic FA $\times 4)+(\%$ hexaenoic FA $\times 5)$. 
Table 4. Least squares means (time 0 data used as a covariate) of plasma activity of circulating enzymes (IU/L) originating from the liver at d 30 of the experimental period

\begin{tabular}{lcccccc}
\hline & \multicolumn{5}{c}{${\text { Experimental } \operatorname{diet}^{2}}$} \\
\cline { 2 - 5 } Enzyme activity $^{1}(\mathrm{IU} / \mathrm{L})$ & $\mathrm{C}$ & $\mathrm{L}$ & $\mathrm{LE}$ & LEP & SEM & $P$-value (treatment) \\
\hline ASAT & $90.1^{\mathrm{a}}$ & $111.5^{\mathrm{b}}$ & $127.8^{\mathrm{b}}$ & $120.4^{\mathrm{b}}$ & 8.00 & 0.02 \\
ALAT & 27.6 & 26.5 & 23.7 & 26.3 & 1.90 & NS \\
GGT & 27.7 & 28.1 & 29.7 & 29.2 & 1.86 & NS \\
\hline
\end{tabular}

${ }^{\mathrm{a}, \mathrm{b}}$ Least squares means in the same row with different superscript letters are significantly different, $P<0.05$. NS: $P>0.1$.

${ }^{1} \mathrm{ASAT}=$ aspartate aminotransferase; ALAT $=$ alanine aminotransferase; GGT = gamma-glutamyl transpeptidase.

${ }^{2}$ Cows were given a maize-silage-based diet (control, $\mathrm{C}, \mathrm{n}=6$ ) or the same diet enriched with 18:3 n-3 from extruded linseed (50 g of oil/kg of diet $\mathrm{DM})$ provided alone $(\mathrm{L}, \mathrm{n}=6)$ or with vitamin $\mathrm{E}(375 \mathrm{IU} / \mathrm{kg}$ of diet DM; LE, $\mathrm{n}=6)$ or with vitamin $\mathrm{E}$ plus plant extracts rich in polyphenols (10 g/kg of diet DM; LEP, $\mathrm{n}=5)$.

\section{Plasma Lipoperoxidation Markers}

Production of MDA was generally low in plasma of our cows (Table 6), but it reached $0.127 \mu \mathrm{g} / \mathrm{mL}$ in plasma of the LE group. At d 30, plasma $\alpha$-tocopherol was lower in groups $\mathrm{C}$ and $\mathrm{L}(3.1 \mu \mathrm{g} / \mathrm{mL} ; P<0.05)$ than in groups LE and LEP (17 and $14 \mu \mathrm{g} / \mathrm{mL}$, respectively; $P<0.05)$. Thus, dietary vit $\mathrm{E}(7,500 \mathrm{IU} /$ cow per day $)$ supplied alone or with PERP led to a 4-fold increase in vit $\mathrm{E}(P<0.05)$ compared with that in groups $\mathrm{C}$ and L. In addition, plasma $\alpha$-tocopherol was lower in group LEP than in group LE $(-19 \% ; P<0.05)$. Plasma TAS showed no change regardless of diet (Table 6).

\section{DISCUSSION}

Plant extracts rich in polyphenols are a putative source of antioxidants to prevent plasma lipoperoxidation in ruminants fed PUFA-rich lipid supplements, especially 18:3 n-3-rich linseed. Four PERP have recently been identified and tested on rats and sheep at maintenance (without strong metabolic requirements) and fed an 18:3 n-3-enriched diet. The combination of PERP with vit $\mathrm{E}$ was able to effectively protect these animals from lipoperoxidation (particularly in plasma) and would act via complementary mechanisms of action in the lipoperoxidation chain reaction [Gladine et al., 2007; C. Gladine, E. Rock, C. Morand (all of INRA, UMR1019, St-Genès-Champanelle, France), D. Bauchart, D. Durand (both of INRA, UR1213, StGenès-Champanelle, France); unpublished data]. Our experiment aimed at investigating the effect of an 18:3 n-3-enriched diet on plasma lipoperoxidation in midlactation cows and the effectiveness of vit $\mathrm{E}$ associated with PERP for preventing plasma lipoperoxidation.

\section{Effects of Dietary 18:3 n-3 on Plasma Lipids and Peroxidizability}

Hyperphospholipemia and hypercholesterolemia observed in cows fed a 30-d diet including extruded linseed supplements ( $50 \mathrm{~g}$ of oil $/ \mathrm{kg}$ of diet DM) confirmed previous reports on dairy cows given 18:3 n-3-rich diets (30 g of linseed oil $/ \mathrm{kg}$ of diet DM; Loor et al., 2005), steers given $40 \mathrm{~g}$ of oil $/ \mathrm{kg}$ of diet DM (Scislowski et al., 2005a) and sheep given $63 \mathrm{~g}$ of oil $/ \mathrm{kg}$ of diet DM [C. Gladine, E. Rock, C. Morand (all of INRA, UMR1019, St-Genès-Champanelle, France), D. Bauchart, D. Durand (both of INRA, UR1213, St-Genès-Champanelle, France); unpublished data] supplied by extruded lin-

Table 5. Least squares means (time 0 data used as a covariate) of lipid susceptibility to peroxidation in cow plasma at d 30 of the experimental period

\begin{tabular}{|c|c|c|c|c|c|c|}
\hline Item & \multicolumn{4}{|c|}{ Experimental $\operatorname{diet}^{1}$} & SEM & $\underset{\text { (treatment) }}{P \text {-value }}$ \\
\hline $\mathrm{CD}^{2}$ lag phase (min) & $17.4^{\mathrm{a}}$ & $15.1^{\mathrm{a}}$ & $17.0^{\mathrm{a}}$ & $21.6^{\mathrm{b}}$ & 1.12 & 0.007 \\
\hline Maximal production of $\mathrm{CD}\left(\mathrm{A}_{234 \max }\right)$ & $277.8^{\mathrm{a}}$ & $354.2^{\mathrm{b}}$ & $364.5^{\mathrm{b}}$ & $339.6^{\mathrm{ab}}$ & 24.74 & 0.1 \\
\hline
\end{tabular}

${ }^{\mathrm{a}-\mathrm{c}}$ Least squares means in the same row with different superscript letters are significantly different at $P<0.05$. Trends were identified at 0.05 $<P<0.1$.

${ }^{1}$ Cows were given a maize-silage-based diet (control, $\mathrm{C}, \mathrm{n}=6$ ) or the same diet enriched with 18:3 n-3 from extruded linseed (50 g of oil/kg of diet $\mathrm{DM})$ provided alone $(\mathrm{L}, \mathrm{n}=6)$ or with vitamin $\mathrm{E}(375 \mathrm{IU} / \mathrm{kg}$ of diet $\mathrm{DM}$; $\mathrm{LE}, \mathrm{n}=6)$ or with vitamin $\mathrm{E}$ plus plant extracts rich in polyphenols $(10 \mathrm{~g} / \mathrm{kg}$ of diet DM; LEP, $\mathrm{n}=5)$.

${ }^{2} \mathrm{CD}=$ conjugated diene. 
Table 6. Least squares means (time 0 data used as a covariate) of malondialdehyde production, $\alpha$-tocopherol concentration, and total antioxidative status in cow plasma at d 30 of the experimental period

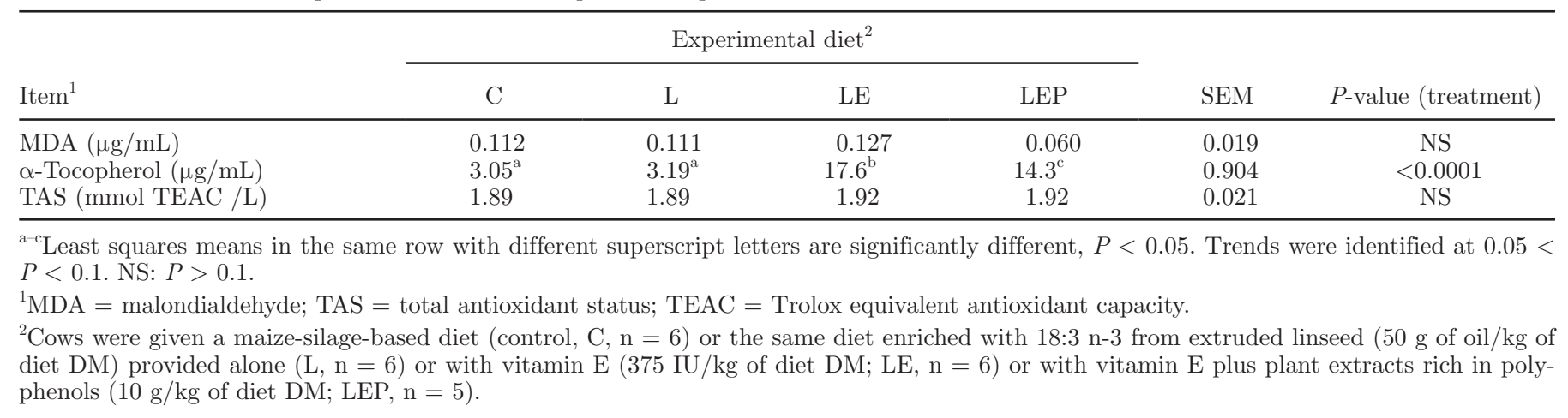

seeds. Hyperphospholipemia and hypercholesterolemia are probably associated with a higher level of light high-density lipoprotein (HDLl) particles, as shown in steers (1.4-fold increase; $P<0.05$ ) given n-6 PUFA (40 $\mathrm{g}$ of oil $/ \mathrm{kg}$ of diet DM) from sunflower seeds (Scislowski et al., 2005b). High-density lipoproteins are the main lipoprotein family involved in blood PL and CE transport in ruminants (representing $80 \%$ of lipoproteins), which increased in ruminants given lipid-supplemented diets (Bauchart, 1993). Furthermore, the modified FA composition in plasma lipids with higher n-3 PUFA in cows given linseed supplement showed that a significant fraction of dietary n-3 PUFA had avoided ruminal biohydrogenation and then were absorbed by the small intestine (Doreau and Ferlay, 1994). Similar FA composition changes were reported in cows (Loor et al., 2005) and steers (Bauchart et al., 2005) given extruded linseed. As a result of lipid supplementation, the $20 \%$ higher plasma PI in our cows given $50 \mathrm{~g}$ of linseed oil/ $\mathrm{kg}$ of diet DM compared with that in cows of group C is slightly higher than reported earlier in dairy cows and sheep ( +8 to $15 \%$ ) given 47 and $63 \mathrm{~g}$ of oil $/ \mathrm{kg}$ of diet DM, respectively [Petit et al., 2004; C. Gladine, E. Rock, C. Morand (all of INRA, UMR1019, St-GenèsChampanelle, France), D. Bauchart, D. Durand (both of INRA, UR1213, St-Genès-Champanelle, France); unpublished data]. Kinetics of $\mathrm{CD}$ generation (i.e., lag phase, oxidation rate, and maximum CD production) are appropriate in vitro indicators of the relative effect of blood lipid enrichment on susceptibility to plasma PUFA oxidation (Schnitzer et al., 1995). The significantly higher maximum CD production noted in cows of group L confirmed the risk of higher susceptibility to lipoperoxidation in plasma of cows given with 18:3 n-3-enriched diets. The higher CD oxidation rate can be attributed to the PI increase caused by numerous bis-allylic positions in the aliphatic chain of 18:3 n-3 and their partially hydrogenated derivatives forming new substrates for peroxidation propagation (Cosgrove et al., 1987). Plasma MDA was assessed to determine the relative intensity of in vivo plasma lipoperoxidation in cows. Surprisingly, the increase in plasma MDA was similar in cows of the control and linseed groups. Contrary to the increase of lipoperoxidation susceptibility (based on PI and CD parameters) observed in vitro, the absence of an in vivo MDA increase would indicate a lack of oxidative stress in the cows fed diet L. Moreover, HPLC sensitivity was 20-fold higher than previously determined with a colorimetric assay kit $(2.5 \mu \mathrm{g} / \mathrm{mL}$ of plasma), detecting aldehydes other than MDA in cows given a non-lipid-supplemented diet (Castillo et al., 2005). The 2 analytical methods differed in their sensitivity, the colorimetric assay being less specific than the HPLC method with UV detection. However, it is obvious in our experiment that the low in vivo plasma MDA values indicated that cows of group L did not experience oxidative stress caused by lipid supplementation or lactation. Vazquez-Anon et al. (2008) claimed that high-producing dairy cows (averaging 40 $\mathrm{kg}$ of DMY) are prone to oxidative stress exacerbated by certain environmental, physiological, and dietary conditions, but our dairy cows were characterized by a mid-range DMY $(32 \mathrm{~kg})$. Moreover, the good breeding practices in our experimental installations, avoiding transport or exercise-induced stress (shown as stress factors in sheep study; Gladine et al., INRA, SaintGenès Champanelle; personal communication), would help to minimize oxidative stress and keep MDA values low. Furthermore, at d 30, the SCC was $<1,000,000$ cells $/ \mathrm{mL}($ mean $=310,000 \pm 236,000$ cells $/ \mathrm{mL})$, and udder and milk aspects were not modified during milking, so no clinical mastitis was noted (Poutrel et al., 1982). Hepatic insufficiency can have a negative effect on cow health and productivity (Bobe et al., 2004) and is strongly correlated to oxidative stress (Mudron et al., 1999). We determined plasma activities of liver enzymes ASAT, ALAT, and GGT as indicators of hepatic health. The fact that the activity of these enzymes did 
not increase or only slightly increased in cows given linseed diets suggests that 18:3 n-3 supplementation did not induce hepatic insufficiency in this experiment.

\section{Effect of Antioxidants on the Oxidative Stability of Plasma}

Plasma $\alpha$-tocopherol levels in our control cows (3.1 $\mu \mathrm{g} / \mathrm{mL}$ ) were similar to those (at $2.2 \mu \mathrm{g} / \mathrm{mL}$ ) reported previously in Holstein cows (Mudron et al., 1999). In our experiment, addition of $\alpha$-tocopherol acetate at the level of $400 \mathrm{mg} / \mathrm{kg}$ of diet DM led to a 4 -fold increase in plasma vit $\mathrm{E}$, similar to the 3.8 -fold increase observed in sheep given $200 \mathrm{mg}$ of $\alpha$-tocopherol acetate/ $\mathrm{kg}$ of diet DM [C. Gladine, E. Rock, C. Morand (all of INRA, UMR1019, St-Genès-Champanelle, France), D. Bauchart, D. Durand (both of INRA, UR1213, St-GenèsChampanelle, France); unpublished data]. In animals of group LEP, plasma vit E decrease could be due to an increase of mammary gland uptake, because animals from group LEP had higher (but not significant) milk yield (Ferlay et al., 2009) and a slightly higher milk vit E level (data not shown) than the LE group. Here, vit E supplementation in cows receiving a lipid-rich diet had a restrictive effect on the in vitro oxidation rate. As demonstrated in in vitro studies (Brigelius-Flohe and Traber, 1999) and in vivo experiments on sheep [C. Gladine, E. Rock, C. Morand (all of INRA, UMR1019, St-Genès-Champanelle, France), D. Bauchart, D. Durand (both of INRA, UR1213, St-Genès-Champanelle, France); unpublished data], vit E probably did not act at the initiation phase of lipoperoxidation chain reactions but rather via the lipophilic peroxyl radical trapping (by conversion into $\alpha$-tocopheroxyl radicals) leading to a slowdown of the propagation phase. However, because the cows fed 18:3 n-3-rich diets showed low oxidative stress (low MDA increase), there was little or no action of vit $\mathrm{E}$ as peroxyl radical trapper in these conditions. Cow plasma MDA levels were not reduced by vit $\mathrm{E}$ alone, which is consistent with results reported in mouse receiving PUFA-rich diets (Hasty et al., 2007). Nevertheless, the lipid-rich diet increased susceptibility to lipoperoxidation (as shown by PI, CD oxidation rate, and maximal production of CD), leading to a need for plasma protection. Hence, vit $\mathrm{E}$ in association with other antioxidant sources is known to increase PUFA protection against peroxidation (Gladine et al., 2007). In our lactating cows, the vit E plus PERP mix was significantly more effective than vit $\mathrm{E}$ alone in protecting plasma lipids against lipoperoxidation, because it increased the in vitro resistance phase duration $(+43 \%$ in LEP vs. L group; $P<0.05$ ). Moreover, although the treatment effect on MDA production was not significant $(P=0.18)$, the vit E plus PERP mix appeared to decrease the in vivo low plasma MDA levels more effectively than vit $\mathrm{E}$ alone $(-53 \%$ in LEP vs. LE group; $P=0.04$ ). Comparative studies performed in our laboratory on rat and sheep models proved the effectiveness of the mixture vit $\mathrm{E}$ and PERP in delivering a highly protective effect increasing the resistance (lag phase) and decreasing the propagation (oxidation rate) phases of the lipoperoxidation chain reactions [Gladine et al., 2007; C. Gladine, E. Rock, C. Morand (all of INRA, UMR1019, St-Genès-Champanelle, France), D. Bauchart, D. Durand (both of INRA, UR1213, StGenès-Champanelle, France); unpublished data]). This higher resistance phase could be due to polyphenols of PERP, scavengers of lipoperoxidation initiators (Thavasi et al., 2006; Gladine et al., 2007), and of metal chelators (Rodrigo and Bosco, 2006). Polyphenols involved in these reactions could include flavonoids that inhibit or stimulate endogenous antioxidant pathways by modulating gene expression of protein and lipid kinase signaling pathways (Williams et al., 2004). This is consistent with measurements realized in the liver of rats given vit E and PERP (Gladine et al., 2007) showing a high catalase activity, thus limiting formation of lipoperoxidation initiators by conversion of hydrogen peroxide $\left(\mathrm{H}_{2} \mathrm{O}_{2}\right)$ into water and molecular oxygen. Hence, a combination of plant polyphenols acting at the initiation step and vit E acting at the propagation step would be important in term of complementarities of their respective antioxidative sites of action. In our study, the greater in vitro reduction of lipoperoxidation rate in the plasma of cows given vit $\mathrm{E}+$ PERP compared with vit $\mathrm{E}$ alone also suggests that polyphenols play a chain-breaking antioxidant role as mentioned earlier (Rodrigo and Bosco, 2006). This could explain synergistic interactions with $\alpha$-tocopherol in plasma. Moreover, the complementary physicochemical characteristics of hydrophilic polyphenols and lipophilic $\alpha$-tocopherol had been suggested (Yeum et al., 2004). Because of its hydrophobic nature, vit $\mathrm{E}$ is transported in plasma by low- and very low-density lipoproteins before being incorporated into the lipid bilayers (Khalil, 2002). In contrast, polyphenols such as our PERP mix could be present at the aqueous-lipid interface (Manach et al., 2004) where, close to vit E, they could favor the recycling of the $\alpha$-tocopheroxyl radical, as shown in vitro for green tea polyphenols (Zhou et al., 2005) and for catechins in micellar solutions (Mukai et al., 2005). A second potentially relevant property of PERP would be their ability to spare $\alpha$-tocopherol by limiting the initiation of the propagation phase, as observed in vitro in liver microsomes of rats given PUFA and vit $\mathrm{E}$ associated with plant flavonoid-rich diets (Fremont et al. 1998). Nevertheless, this putative vit E regeneration was not possible in the plasma of our cows, because in 
the present study vit $\mathrm{E}$ was more consumed when associated with PERP, probably because of vit $\mathrm{E}$ uptake by tissues such as the mammary gland. Nevertheless, our results are similar to the findings of Giannenas et al. (2005) who reported a synergistic effect between vit $\mathrm{E}$ and oregano to prevent lipoperoxidation in poultry tissues but with no increase in tissue $\alpha$-tocopherol concentration when oregano ( 5 or $10 \mathrm{~g} / \mathrm{kg}$ ) was added to the vit E-supplemented diet. Vitamin E associated with PERP slightly protected cow plasma against lipoperoxidation damage, as shown by lower MDA levels in lactating cows from group LEP than in controls, which is consistent with results reported in growing sheep [C. Gladine, E. Rock, C. Morand (all of INRA, UMR1019, St-Genès-Champanelle, France), D. Bauchart, D. Durand (both of INRA, UR1213, St-Genès-Champanelle, France); unpublished data].

\section{CONCLUSIONS}

This is the first demonstration that a combination of 2 types of antioxidants is able to prevent plasma lipoperoxidation processes in lactating dairy cows receiving 18:3 n-3-rich diets. This observation further supports the preventive role of antioxidant mixtures against lipoperoxidation damage generated by high oxidative stress. The protective antioxidant action is probably due to the PERP activity or very likely to the combination of the lipophilic (vitamin E) and hydrophilic (PERP) properties having the dual ability to 1) break the lipoperoxidation chain, thus limiting the propagation phase, and 2) reduce the quantity of oxygenated radical species, thereby inhibiting the lipoperoxidation initiation phase. These effects will need to be tested in high-producing lactating cows submitted to substantial stress conditions such as animals in the early-lactation period or in animals subjected to mastitis.

\section{ACKNOWLEDGMENTS}

This work was partly funded by the TRUEFOOD (Traditional United Europe Food) integrated project financed by the European Commission under the 6th Framework Programme for RTD (FOODCT-2006-016264). We thank Phytosynthese (Riom, France) for providing the original antioxidant mixture of plant extracts rich in polyphenol. We also address specific thanks to experimental cowshed workers (INRA, Orcival, France); to Françoise Duboisset, Marinett Martinaud, Anne-Sophie Bage, Christiane Legay, and Agnès Thomas for their technical assistance, and to Anne De La Foye (all of INRA, Clermont-Ferrand/ Theix, France) for her statistical assistance.

\section{REFERENCES}

Agarwal, R., and S. D. Chase. 2002. Rapid fluorimetric-liquid chromatographic determination of malondialdehyde in biological samples. J. Chrom. B Anal. Technol Biomed. Life Sci. 775:121126.

Aurousseau, B. 2002. Oxygen radicals in farm animals. Physiological effects and consequences on animal products. Prod. Anim. 15:6782 .

Bauchart, D. 1993. Lipid absorption and transport in ruminants. J. Dairy Sci. 76:3864-3881.

Bauchart, D., and B. Aurousseau. 1981. Postprandial lipids in blood plasma of preruminant calves. J. Dairy Sci. 64:2033-2042.

Bauchart, D., C. Gladine, D. Gruffat, L. Leloutre, and D. Durand. 2005. Effects of diets supplemented with oil seeds and vitamin $\mathrm{E}$ on specific fatty acids of rectus abdominis muscle in Charolais fattening bulls. Pages 431-436 in Indicators of Milk and Beef Quality. J. F. Hocquette and S. Gigli, ed. EAAP Publication No 112. EAAP, Rome, Italy.

Bobe, G., J. W. Young, and D. C. Beitz. 2004. Invited review: Pathology, etiology, prevention, and treatment of fatty liver in dairy cows. J. Dairy Sci. 87:3105-3124.

Brigelius-Flohe, R., and M. G. Traber. 1999. Vitamin E: Function and metabolism. FASEB J. 13:1145-1155.

Castillo, C., J. Hernandez, A. Bravo, M. Lopez-Alonso, V. Pereira, and J. L. Benedito. 2005. Oxidative status in late pregnancy and early lactation in dairy cows. Vet. J. 169:286-292.

Chilliard, Y., F. Glasser, A. Ferlay, L. Bernard, J. Rouel, and M. Doreau. 2007. Diet, rumen biohydrogenation and nutritional quality of cow and goat milk fat. Eur. J. Lipid Sci. Technol. 109:828-855.

Cosgrove, J. P., D. F. Church, and W. A. Pryor. 1987. The kinetics of the autoxidation of polyunsaturated fatty acids. Lipids 22:299304.

Cuvelier, C., O. Dotreppe, and L. Istasse. 2003. Chemistry, nutritional sources and analyses of vitamin E. Ann. Med. Vet. 147:315-324.

Doreau, M., and A. Ferlay. 1994. Digestion and utilization of fatty acids by ruminants. Anim. Feed Sci. Technol. 45:379-396.

Elmadfa, I., and A. Walter. 1981. Accumulation of tocopherol in various organs. Int. J. Vitam. Nutr. Res. 51:284-292.

Esterbauer, H., G. Striegl, H. Puhl, and M. Rotheneder. 1989 Continuous monitoring of in vitro oxidation of human low density lipoprotein. Free Rad. Res. Commun. 6:67-75.

Ferlay, A., B. Martin, S. Lerch, Ph. Pradel, and Y. Chilliard. 2009. Effects of supplementation of maize silage diets with extruded linseeds, vitamin $\mathrm{E}$ or plant extracts rich in polyphenols, and morning vs. evening milking on milk fatty acid profiles in Holstein and Montbeliarde cows. Animal (accepted for publication).

Folch, J., M. Lees, and G. H. Sloane Stanley. 1957. A simple method for the isolation and purification of total lipids from animal tissues. J. Biol. Chem. 226:497-509.

Fremont, L., M. T. Gozzelino, M. P. Franchi, and A. Linard. 1998. Dietary flavonoids reduce lipid peroxidation in rats fed polyunsaturated or monounsaturated fat diets. J. Nutr. 128:1495-1502.

Giannenas, I. A., P. Florou-Paneri, N. A. Botsoglou, E. Christaki, and A. B. Spais. 2005. Effect of supplementing feed with oregano and/or alpha-tocopheryl acetate on growth of broiler chickens and oxidative stability of meat. J. Anim. Feed Sci. 14:521-535.

Gladine, C., C. Morand, E. Rock, D. Bauchart, and D. Durand. 2007. Plant extracts rich in polyphenols (PERP) are efficient antioxidants to prevent lipoperoxidation in plasma lipids from animals fed n-3 PUFA supplemented diets. Anim. Feed Sci. Technol. 136:281296.

Goupy, P., E. Vulcain, C. Caris-Veyrat, and O. Dangles. 2007. Dietary antioxidants as inhibitors of the heme-induced peroxidation of linoleic acid: Mechanism of action and synergism. Free Radic. Biol. Med. 43:933-946.

Hasty, A. H., M. L. Gruen, E. S. Terry, B. K. Surmi, R. D. Atkinson, L. Gao, and J. D. Morrow. 2007. Effects of vitamin E on oxidative stress and atherosclerosis in an obese hyperlipidemic mouse model. J. Nutr. Biochem. 18:127-133. 
INRA. 1988. Alimentation des bovins, ovins et caprins. Institut National de la Recherche Agronomique, Paris, France.

Jacob, R. A., and B. J. Burri. 1996. Oxidative damage and defense. Am. J. Clin. Nutr. 63:985S-990S.

Khalil, A. 2002. Molecular mechanisms of the protective effect of vitamin E against atherosclerosis. Can. J. Physiol. Pharmacol. 80:662-669.

King, R. A., M. M. Mano, and R. J. Head. 1998. Assessment of isoflavonoid concentrations in Australian bovine milk samples. J. Dairy Res. 65:479-489.

Loor, J. J., A. Ferlay, A. Ollier, K. Ueda, M. Doreau, and Y. Chilliard. 2005. Relationship among trans and conjugated fatty acids and bovine milk fat yield due to dietary concentrate and linseed oil. J. Dairy Sci. 88:725-740.

Manach, C., A. Scalbert, C. Morand, C. Remesy, and L. Jimenez 2004. Polyphenols: Food sources and bioavailability. Am. J. Clin. Nutr. 79:727-747.

Miller, E. R., R. Pastor-Barriuso, D. Dalal, R. A. Riemersma, L. J. Appel, and E. Guallar. 2005. Meta-analysis: High-dosage vitamin E supplementation may increase all-cause mortality. Ann. Intern. Med. 142:37-46.

Miller, J. K., E. Brzezinska-Slebodzinska, and F. C. Madsen. 1993 Oxidative stress, antioxidants, and animal function. J. Dairy Sci. 76:2812-2823.

Mudron, P., J. Rehage, K. Qualmann, H. P. Sallmann, and H. Scholz. 1999. A study of lipid peroxidation and vitamin $\mathrm{E}$ in dairy cows with hepatic insufficiency. Zentralbl. Veterinarmed. A 46:219224 .

Mukai, K., S. Mitani, K. Ohara, and S. Nagaoka. 2005. Structureactivity relationship of the tocopherol-regeneration reaction by catechins. Free Rad. Biol. Med. (Paris) 38:1243-1256.

Petit, H. V., C. Germiquet, and D. Lebel. 2004. Effect of feeding whole, unprocessed sunflower seeds and flaxseed on milk production, milk composition, and prostaglandin secretion in dairy cows. J. Dairy Sci. 87:3889-3898.

Poutrel, B., and P. Rainard. 1982. Predicting the probability of quarter infection (by major pathogens) from somatic cell concentration. Am. J. Vet. Res. 43:1296-1299.
Rodrigo, R., and C. Bosco. 2006. Oxidative stress and protective effects of polyphenols: Comparative studies in human and rodent kidney. A review. Comp. Biochem. Physiol. C Toxicol. Pharm. 142:317-327.

Schnitzer, E., I. Pinchuk, M. Fainaru, Z. Schafer, and D. Lichtenberg. 1995. Copper-induced lipid oxidation in unfractionated plasma: The lag preceding oxidation as a measure of oxidation-resistance. Biochem. Biophys. Res. Commun. 316:854-861.

Scislowski, V., D. Bauchart, D. Gruffat, P. M. Laplaud, and D. Durand. 2005a. Effects of dietary n-6 or n-3 polyunsaturated fatty acids protected or not against ruminal hydrogenation on plasma lipids, and their susceptibility to peroxidation in fattening steers. J. Anim. Sci. 83:2162-2174.

Scislowski, V., D. Bauchart, D. Gruffat, P. M. Laplaud, and D. Durand. 2005b. Effect of dietary n-6 and n-3 polyunsaturated fatty acids on peroxidizability of lipoproteins in steers. Lipids 40:1245-1256.

Thavasi, V., L. P. Leong, and R. P. Bettens. 2006. Investigation of the influence of hydroxy groups on the radical scavenging ability of polyphenols. J. Phys. Chem. A 110:4918-4923.

Vazquez-Anon, M. J. Nocek, G. Bowman, T. Hampton, C. Atwell, P. Vazquez, and T. Jenkins. 2008. Effects of feeding a dietary antioxidant in diets with oxidized fat on lactation performance and antioxidant status of the cow. J. Dairy Sci. 91:3165-3172.

Williams, R. J., J. P. Spencer, and C. Rice-Evans. 2004. Flavonoids Antioxidants or signalling molecules? Free Rad. Biol. Med. (Paris) 36:838-849.

Yang, C. S., J. M. Landau, M. T. Huang, and H. L. Newmark. 2001. Inhibition of carcinogenesis by dietary polyphenolic compounds. Annu. Rev. Nutr. 21:381-406.

Yeum, K. J., R. M. Russell, N. I. Krinsky, and G. Aldini. 2004. Biomarkers of antioxidant capacity in the hydrophilic and lipophilic compartments of human plasma. Arch. Biochem. Biophys. 430:97-103.

Zhou, B., L. M. Wu, L. Yang, and Z. L. Liu. 2005. Evidence for alphatocopherol regeneration reaction of green tea polyphenols in SDS micelles. Free Rad. Biol. Med. (Paris) 38:78-84. 